\title{
Podróże za marzeniami. Kultura uzdrowiskowa w Europie, Bożena Płonka-Syroka, Paulina Suchecka, Wrocław 2021, ss. 131, rec. Bożena Urbanek
}

DOI: 10.4467/12311960MN.21.017.15248

Album pod podanym powyżej tytułem jest pokłosiem wystawy prezentowanej ostatnio we wrocławskim Muzeum Etnograficznym. Pomysłodawcami wystawy i albumu stały się prof. dr hab. Bożena Płonka-Syroka - pracownik naukowy Uniwersytetu Medycznego we Wrocławiu i Paulina Suchocka - kustosz wspomnianego muzeum. Wystawa była owocem kilkuletniej już współpracy akademickich historyków medycyny z tą wrocławską instytucją ${ }^{1}$. Dodać należy, że ekspozycja ta, jak zaznaczyła we wstępie do albumu Elżbieta Berent, oparta została - i to w dużej części - na zbiorach dolnośląskich muzeów, w tym np. karkonoskiego w Jeleniej Górze, Sportu i Turystki w Karpaczu, Ośrodka Kultury i Sztuki i wielu innych, które udostępniły m.in. ilustracje, fotografie, listy kuracjuszy z początków XX w., pochodzące z 11 dolnośląskich uzdrowisk, w większości nadal funkcjonujących.

Album oprócz wspomnianego już wstępu składa się z czterech części przygotowanych przez jego autorki. W kolejności P. Suchocka rozpoczęła opowieść o śląskich zdrojowiskach rozdziałem zatytułowanym: Gość kapielowy, w dalszych B. Płonka-Syroka opisała Kształtowanie się modelu kultury uzdrowiskowej / Summary The Spa Culture in Europe. W zasadniczej części prezentowanego albumu Suchocka przedstawiła 11 dolnośląskich zdrojowisk w następującej, alfabetycznej kolejności: Cieplice Zdr., Czerniawa Zdr., Długopole Zdr., Duszniki Zdr., Jedlina Zdr., Kudowa Zdr., Lądek Zdr., Polanica Zdr., Przerzeczyn Zdr., Szczawno Zdr., Świerardów Zdr. Przytoczono również źródła dotyczące poszczególnych uzdrowisk, jak i cytatów towarzyszących opisom oraz pochodzenie zamieszczonych $\mathrm{w}$ albumie ilustracji.

Warto bowiem zaznaczyć, że poszczególne części dotyczące 11 dolnośląskich uzdrowisk zostały bogato zilustrowane unikatowymi, jak zaznaczono, pochodzącymi z początków XX w. fotogramami, widokami miejscowych zabytków, w tym obiektów kuracyjnych, jak: domy zdrojowe i ich wnętrza, łazienki i inne zakłady przyrodolecznicze, promenady i parki uzdrowiskowe. W albumie zawarto też zdjęcia

\footnotetext{
${ }^{1} \mathrm{~W}$ tamtejszym muzeum np. w roku 2013 zorganizowano ekspozycję „Kultura medyczna islamu,” opartą w dużej mierze na zbiorach uczelnianego Muzeum Farmacji.
} 
ówczesnych kuracjuszy, reklam, ale i cenników oferowanych usług leczniczych oraz produktów. Łącznie zamieszczono w nim przeszło 130 starannie dobranych do całości reprodukcji.

Publikacja, jak się wydaje, w sposób realistyczny oddaje klimat uzdrowisk początków XX w., ale służyć może i dziś hasłu przytoczonemu przez autorki: odbycia podróży - będącej niejako zachętą - do miejsc, gdzie „uzyskać można zdrowie”, a nawet porzucić czasem uciążliwą codzienność. 